\title{
Stable isotopes reveal regional heterogeneity in the pre-breeding distribution and diets of sympatrically breeding Pygoscelis spp. penguins
}

\author{
Michael J. Polito ${ }^{1, *}$, Heather J. Lynch ${ }^{2}$, Ron Naveen ${ }^{3}$, Steven D. Emslie ${ }^{1}$ \\ ${ }^{1}$ Department of Biology and Marine Biology, University of North Carolina Wilmington, 601 South College Road, Wilmington, \\ North Carolina 28403, USA \\ ${ }^{2}$ Department of Biology, 3237 Biology-Psychology Building, University of Maryland, College Park, Maryland 20742, USA \\ ${ }^{3}$ Oceanites Inc., PO Box 15259, Chevy Chase, Maryland 20825, USA
}

\begin{abstract}
While the foraging ecology of the Adélie penguin Pygoscelis adeliae and gentoo penguin $P$. papua has been well studied, little is known on the distribution and diet of these species outside the breeding season. In the present study we used stable carbon $\left(\delta^{13} \mathrm{C}\right)$ and nitrogen $\left(\delta^{15} \mathrm{~N}\right)$ isotope analyses of eggshells to examine the pre-breeding diets and foraging habitats of female Adélie and gentoo penguins from 23 breeding colonies along the eastern and western Antarctic Peninsula (AP), South Shetland Islands, and South Orkney Islands, in 2006. Adélie penguin eggshells from the eastern AP, South Shetland Islands, and South Orkney Islands shared similar isotopic signatures and were significantly lower in both $\delta^{13} \mathrm{C}$ and $\delta^{15} \mathrm{~N}$ values than eggshells from birds breeding along the western AP. This result suggests that Adélie penguin populations that are geographically separated during the breeding season by the Adélie 'gap,' a $400 \mathrm{~km}$ region in the western AP devoid of breeding Adélie penguins, also inhabit geographically distinct habitats during the late winter prior to the breeding season. To a lesser degree, gentoo penguin eggshell isotope values also varied across breeding colonies, which likely reflects local scale variation in their near-shore foraging grounds. Furthermore, unlike the breeding period when krill (primarily Euphausia superba) dominates penguin diets in these regions, our findings suggest that fish and/or other high trophic-level prey species comprise a significant portion (46.8 to $62.9 \%$ ) of female Adélie and gentoo penguin diets prior to breeding.
\end{abstract}

KEY WORDS: Stable isotope analysis · Adélie penguin · Gentoo penguin - Pygoscelis adeliae . Pygoscelis papua $\cdot$ Distribution $\cdot$ Diet

\section{INTRODUCTION}

Studies of the foraging ecology of penguins have been commonly used as a cost-efficient method to monitor the Antarctic marine ecosystem (Trivelpiece et al. 1990, Reid \& Croxall 2001). These studies are of increased relevance in the Antarctic Peninsula (AP), where recent changes in climate, sea ice conditions, and the abundance of Antarctic krill Euphausia superba have been suggested to be responsible for contrasting population changes in Pygoscelis spp. penguins (Fraser \& Hofmann 2003, Forcada et al. 2006, Hinke et al. 2007). For example, there is evidence of a widespread and long-term decrease in Adélie penguin $P$. adeliae populations in the $\mathrm{AP}$, while gentoo penguin $P$. papua populations are stable or increasing, with recent expansions in the southernmost part of their breeding range (Lynch et al. 2008).

While the foraging ecology of Adélie and gentoo penguins has been well studied, research has been limited to a few breeding colonies throughout this large region. Adélie penguins breed in the AP region from Marguerite Bay to Anvers Island along the western AP and in the eastern AP, South Shetland Islands, and South Orkney Islands (Fig. 1a). Gentoo penguins breed between the Yalour Islands and Trinity Island 


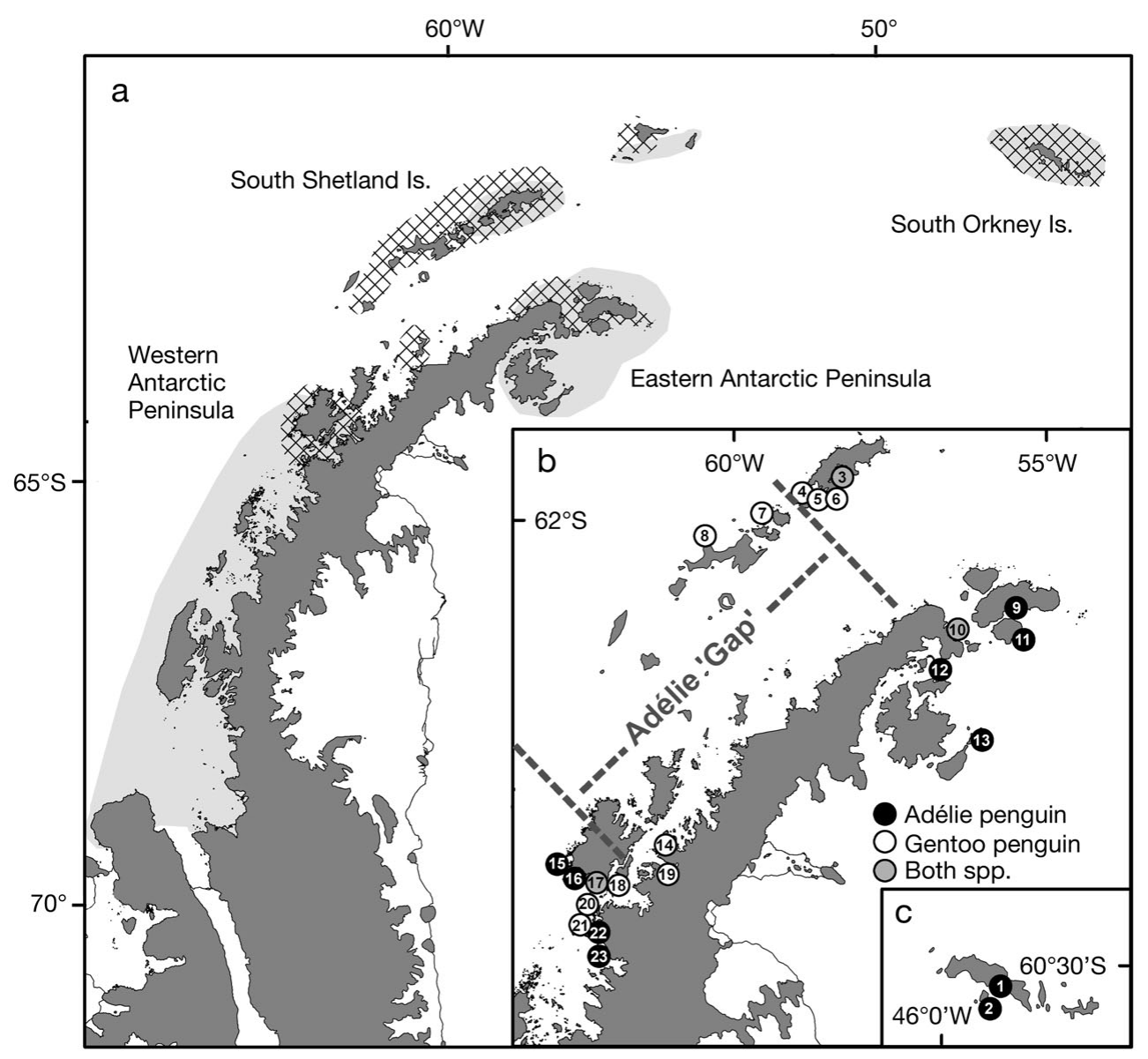

Fig. 1. Pygoscelis adeliae and P. papua. (a) Summer breeding distributions of Adélie penguins (light shading) and gentoo penguins (cross hatch), and (b,c) location of 23 breeding colonies sampled for eggshells in the South Orkney Islands, South Shetland Islands, eastern and western Antarctic Peninsula during austral summer of 2006-07. Breeding distributions adapted from data in Woehler (1993) and Lynch et al. (2008). Note the conspicuous gap in the breeding range of Adélie penguins along the western Antarctic Peninsula and South Shetlands Islands (the Adélie gap; dashed line). See Tables 2 \& 3 for the corresponding site names for each of the 23 breeding colonies

along the Western AP, in a few locations in the eastern $\mathrm{AP}$, and throughout much of the South Shetland and South Orkney Islands (Fig. 1a) (Woehler 1993, Lynch et al. 2008). During the breeding season, Adélie penguins in the AP primarily feed on krill and small amounts of fish, while gentoo penguin diets are more flexible and contain variable amounts of krill and fish (Volkman et al. 1980, Karnovsky 1997, Miller et al. 2009). While these species' distributions overlap, it is thought that during breeding, gentoo penguins forage preferentially inshore, in benthic habitats, while Adélie penguins often forage offshore, in pelagic waters (Trivelpiece et al. 1987, Kokubun et al. 2010, Wilson 2010).

In contrast, little is known about the diets and distributions of these species outside of the breeding season. The few existing studies of winter diets of Adélie and gentoo penguins in the AP suggest that high trophic-level prey, such as fish and squid, are dominant prey items (Jablonski 1985, Ainley et al. 1992,
Coria et al. 2000). During winter, Adélie penguins are concentrated in the pack ice, while gentoo penguins are generally non-migratory and remain near their breeding colonies year-round (Fraser et al. 1992, Wilson et al. 1998, Tanton et al. 2004). While the exact wintering distributions of Adélie penguin populations that breed in the AP are unknown, high numbers have been observed in the winter pack ice east of the AP in the Weddell Sea and west of the AP in the Bellingshausen Sea (Ainley et al. 1992, Fraser et al. 1992, Fraser \& Trivelpiece 1996, Chapman et al. 2004, Ribic et al. 2008). This finding, along with the distinctive gap in the breeding range of Adélie penguins between Anvers Islands in the south and King George Island and the Eastern AP in the north (the Adélie 'gap', Fig. 1b) (Woehler 1993), has led some to hypothesize that Adélie penguins in the AP may comprise 2 distinct populations: one that breeds from Anvers Island to the south along the western AP and winters in the Bellingshausen Sea, and another that breeds in the 
South Orkney Islands, South Shetland Islands, and eastern AP, and winters in the Weddell Sea (Fraser et al. 1992, Fraser \& Trivelpiece 1996, Trivelpiece \& Fraser 1996). However, there is currently little evidence to support or reject this hypothesis, and to our knowledge only 1 published study has tracked breeding Adélie penguins in this region from their colony to their winter habitats (Dunn et al. in press).

The use of naturally occurring stable isotopes to describe the foraging ecology of penguins has become commonplace, as the stable isotope ratios of carbon $\left(\delta^{13} \mathrm{C}\right)$ and nitrogen $\left(\delta^{15} \mathrm{~N}\right)$ in animal tissues are largely determined by isotopic abundances in an animal's food web (Ainley et al. 2003, Cherel \& Hobson 2007, Cherel 2008, Tierney et al. 2008, Polito et al. 2009). Nitrogen isotope values are commonly used to infer trophic level and diets, while carbon values help trace vertical trends in habitat use (benthic vs. pelagic) as well as the geographic location of foraging habitats (Quillfeldt et al. 2005, Cherel \& Hobson 2007, Quilfeldt et al. 2010). Moreover, this technique shows great promise in elucidating the diets and foraging distributions of seabirds outside the breeding season when birds are away from their breeding colony (Quillfeldt et al. 2005, Cherel et al. 2007, Phillips et al. 2009, Polito et al. 2009).

Previous studies on quail Coturnix japonica and ostrich Struthio camelus have found that stable isotope analysis of eggshell provides information on diet during a brief period prior to breeding, as eggshell components are derived from plasma through the metabolism of recently assimilated foods (Simkiss \& Tyler 1958, Hobson 1995, Johnson 1995, Johnson et al. 1998). However, this is likely not the case in birds that utilize significant amounts of stored nutrient reserves during egg-laying, such as penguins (Astheimer \& Grau 1985, Hobson 1995). Female Adélie penguins fast for up to $2 \mathrm{wk}$ prior to egg-laying, and approximately $75 \%$ of the energy content of the clutch is deposited after females have begun their fast (Astheimer \& Grau 1985). Female gentoo penguins also fast before egg-laying, losing $12 \%$ of their total body mass at a rate of $85 \mathrm{~g} \mathrm{~d}^{-1}$ prior to laying their first egg (Trivelpiece \& Trivelpiece 1990). Therefore, it is likely that the isotopic values of Adélie penguin and to a lesser extent gentoo penguin eggshells reflect an integration of dietary information during late-winter foraging prior to the penguins' return to their breeding colonies and/or the onset of the egg-laying fast.

In the present study we examined the pre-breeding diets and foraging habitats of female Adélie and gentoo penguins using stable isotope analysis of eggshells collected from 23 breeding colonies along the eastern and western AP, South Shetland Islands, and South Orkney Islands. Specifically, we tested the hypothesis put forward by Fraser et al. (1992) and others that Adélie penguin breeding populations, which are geogra- phically separated by the Adélie gap, inhabit geographically distinct habitats outside of the breeding season. A recent analysis of the $\delta^{13} \mathrm{C}$ signatures of pelagic primary producers highlighted isotopic differences between the 2 proposed Adélie penguin wintering areas in the Bellingshausen and Weddell Seas (Quillfeldt et al. 2010). Due to these differences, the isotopic signatures of Adélie penguin eggshells should allow for discrimination between populations using these 2 winter habitats prior to breeding. Secondly, we used an isotopic mixing model to quantify the diet composition of female Adélie and gentoo penguins prior to breeding to confirm the few existing studies of winter diets which suggest that high trophic-level prey are important components of diets during this time period (Jablonski 1985, Ainley et al. 1992, Coria et al. 2000). Lastly, we examined how sensitive mixing-model estimates of penguin diet compositions are to variations in isotopic discrimination factors between wild and captive penguin populations.

\section{MATERIALS AND METHODS}

Study area and sample collection. We collected eggshell samples from 23 Adélie and gentoo penguin breeding colonies along the AP (roughly 60 to $66^{\circ} \mathrm{S}$; Fig. 1b,c). This area defines the range of overlap for these 2 species and naturally clusters into 4 regions: the South Orkney Islands, the South Shetland Islands, the western AP, and the eastern AP (Fig. 1a). From November 2006 to February 2007, eggshell samples were collected by researchers based on the tour ship 'National Geographic Endeavour' and several land-based scientific stations. At each breeding colony we opportunistically collected 8 to 20 eggshells from hatched, depredated, addled, or infertile eggs of each species. When sampling in mixed-species colonies, we collected only eggshells that could be identified to species when they were found in close proximity to nests in non-mixed sections of colonies. We cleaned eggshells of organic debris in the field using a toothbrush and water; then dried and stored samples at room temperature prior to further preparation for isotopic analysis.

Penguin prey items were collected during trawls conducted in the vicinity of the AP and South Shetland and South Orkney Islands by the US Antarctic Marine Living Resource Program (AMLR) during the austral summers of 2005-06 to 2008-09. Sampled prey species were representative of the 2 major components of Adélie and gentoo penguin diets in the study area: krill Euphausia superba $(\mathrm{n}=20)$ and fish (Adélie penguin: Pleuragramma antarcticum, $\mathrm{n}=30$; gentoo penguin: Lepidonotothen squamifrons, $\mathrm{n}=10$ ) (Volkman et al. 1980, Karnovsky 1997, Miller et al. 2009). Whole krill and fish samples were kept frozen prior to analysis. 
Sample preparation and isotopic analysis. Eggshell membranes were removed using a Dremel tool with a sanding attachment. Eggshells were then rinsed in distilled water, cleaned of any remaining surface debris, and then ground to a powder using an analytical mill. Isotope values of the organic matrix of penguin eggshells were obtained after the removal of carbonate by dissolving $\sim 10 \mathrm{mg}$ of cleaned eggshell in a silver capsule through titration with five $20 \mu \mathrm{l}$ aliquots of $6 \mathrm{~N}$ $\mathrm{HCl}$. Acidified samples were stored at room temperature under a fume hood for $24 \mathrm{~h}$, then dried for at least $48 \mathrm{~h}$ in an oven at $60^{\circ} \mathrm{C}$. Acidified samples were not rinsed prior to drying and isotopic analysis to avoid biasing $\delta^{15} \mathrm{~N}$ values (Jacob et al. 2005). The mean C:N value of acidified eggshells was $3.8 \pm 0.2$, which closely approached the assumed $\mathrm{C}: \mathrm{N}$ value for pure protein of 3.7 (Fry et al. 2003).

Whole krill and fish samples were homogenized and then dried for $48 \mathrm{~h}$ in an oven at $60^{\circ} \mathrm{C}$. Lipids were then extracted from whole fish and krill samples using a Soxhlet apparatus with a 1:1, petroleum-ether: ethylether solvent mixture for $8 \mathrm{~h}$ (Seminoff et al. 2007). Lipid-extracted prey items were not acidified prior to isotopic analysis. Approximately $0.5 \mathrm{mg}$ of each eggshell, krill and fish sample was loaded into tin cups for $\delta^{13} \mathrm{C}$ and $\delta^{15} \mathrm{~N}$ analysis.

Eggshell, krill and fish tissues were flash-combusted (Costech ECS4010 elemental analyzer) and analyzed for $\delta^{13} \mathrm{C}$ and $\delta^{15} \mathrm{~N}$ through an interfaced Thermo Delta V Plus continuous-flow stable isotope ratio mass spectrometer (CFIRMS). Raw $\delta$ values were normalized on a 2-point scale using depleted and enriched glutamic acid reference materials USGS-40 and USGS-41. Sample precision was $0.1 \%$ and $0.2 \%$ for $\delta^{13} \mathrm{C}$ and $\delta^{15} \mathrm{~N}$ respectively.

Stable isotope abundances are expressed in $\delta$ notation in per mille units $(\%)$, according to the following equation:

$$
\delta X=\left[\left(R_{\text {sample }} / R_{\text {standard }}\right)-1\right] \times 1000
$$

where $X$ is ${ }^{13} \mathrm{C}$ or ${ }^{15} \mathrm{~N}$ and $R$ is the corresponding ratio ${ }^{13} \mathrm{C}:{ }^{12} \mathrm{C}$ or ${ }^{15} \mathrm{~N}:{ }^{14} \mathrm{~N}$. The $R_{\text {standard }}$ values were based on the Vienna PeeDee Belemnite (VPDB) for ${ }^{13} \mathrm{C}$ and atmospheric $\mathrm{N}_{2}$ for ${ }^{15} \mathrm{~N}$.

Statistical and dietary analysis. We grouped eggshell samples by species and region and used separate, univariate ANOVA with 1 factor and 7 levels (1 level for each species-region combination as no gentoo penguin eggshells were collected from the South Orkney Islands). We also applied Tukey-Kramer multiple comparison tests to examine pair-wise differences in $\delta^{13} \mathrm{C}$ and $\delta^{15} \mathrm{~N}$ of eggshells across species and regions. In addition, we examined variation in the isotopic values of eggshells within and across regions in the AP for each species using separate, univariate
ANOVAs with 1 factor (breeding colony) and TukeyKramer multiple comparison tests. To complement the univariate analyses, we used multivariate discriminant analyses with a jackknife (leave-one-out) classification to examine our ability to differentiate between Adélie and gentoo penguin samples and to assign Adélie and gentoo penguins from each region into discrete groups that share similar pre-breeding diets and foraging habitats based on the $\delta^{13} \mathrm{C}$ and $\delta^{15} \mathrm{~N}$ values of their eggshells.

We examined variation in $\delta^{13} \mathrm{C}$ and $\delta^{15} \mathrm{~N}$ of common Adélie and gentoo penguin prey species using univariate ANOVAs. We quantified the contribution of krill Euphausia superba and fish (Pleuragramma antarcticum for Adélie penguins and Lepidonotothen squamifrons for gentoo penguins) to the diets of pre-breeding female penguins in each region by using a single-isotope $\left(\delta^{15} \mathrm{~N}\right)$, 2-source linear mixing model (Phillips \& Gregg 2001). Model results provide standard errors and confidence intervals for source proportion estimates that account for the observed variability in the isotopic signatures for the sources as well as the mixture. We corrected eggshell values for dietary isotopic fractionation using a $\delta^{15} \mathrm{~N}$ discrimination factor of $+1.8 \%$ derived from a captive population of gentoo penguins (Polito et al. 2009). The resulting mixing model-based diet composition estimates were compared across species-region combinations with $t$-tests calculated using the Satterthwaite (1946) approximation for the degrees of freedom. As discrimination factors can vary by species and/or the elemental and isotopic composition of an animal's diet, we performed a sensitivity analysis $(+0.8 \%$ to $+2.8 \%$ by increments of $0.5 \%$ ) in order to examine how sensitive our estimates of female pre-breeding diets might be to possible differences between $\delta^{15} \mathrm{~N}$ discrimination factors in the wild and those estimated in a captive population (Post 2002, Cherel et al. 2005a,b, Caut et al. 2008a, Robbins et al. 2010).

Data were examined for normality and equal variance. All tests were 2-tailed, and significance was assumed at the 0.05 level. Statistical calculations were performed using SAS (version 9.1) and SPSS (version 16.0). All means are presented $\pm S D$, except diet composition estimates resulting from our linear mixing model, which are presented \pm SE.

\section{RESULTS}

\section{Inter-specific and spatial variation in eggshell isotopic values (Figs. $2 \& 3$ )}

We measured significant differences in eggshell $\delta^{15} \mathrm{~N}$ and $\delta^{13} \mathrm{C}$ values across species-region combinations $\left(\delta^{15} \mathrm{~N}: F_{6,375}=13.090, \mathrm{p}<0.001 ; \delta^{13} \mathrm{C}: F_{6,375}=\right.$ 
72.074, $\mathrm{p}<0.001$ ). Post hoc Tukey comparisons suggested that, in general, Adélie penguins have lower eggshell $\delta^{15} \mathrm{~N}$ and $\delta^{13} \mathrm{C}$ values than gentoo penguins, except in the western AP, where Adélie and gentoo penguin eggshells have similar $\delta^{15} \mathrm{~N}$ values, and in the eastern $\mathrm{AP}$, where these 2 species have similar $\delta^{13} \mathrm{C}$ values (Table 1). Discriminant analysis found that isotopic values $\left(\delta^{15} \mathrm{~N}\right.$ and $\left.\delta^{13} \mathrm{C}\right)$ significantly differentiated eggshells of Adélie and gentoo penguins (Wilks' lambda $=0.647, \chi^{2}=161.958, \mathrm{df}=2, \mathrm{p}<0.001$ ). Overall correct assignment after jackknife validation was $79.2 \%(77.2 \%$ of Adélie penguin and $81.3 \%$ of gentoo penguin eggshells). The ability of the resulting discriminant function to correctly assign eggshell samples to species varied by region. Adélie penguin eggshells were correctly assigned to species with an accuracy of $100,100,87.8$, and $46.0 \%$ for eggshells from the South Orkney Islands, South Shetland Islands, eastern AP, and western AP, respectively. Gentoo penguin eggshells were correctly assigned to species with an accuracy of $84.1,21.4$, and $88.7 \%$ for eggshells from the South Shetland Islands, eastern AP, and western $\mathrm{AP}$, respectively.

While we found few differences in Adélie penguin eggshell $\delta^{15} \mathrm{~N}$ and $\delta^{13} \mathrm{C}$ values across breeding colonies in the South Orkney Islands, South Shetland Islands, and the eastern AP, differences between eggshells from these 3 regions and the western AP were relatively more common (Table $2 ; \delta^{15} \mathrm{~N}: F_{12,193}=8.966, \mathrm{p}<$ $0.001 ; \delta^{13} \mathrm{C}: F_{12,193}=9.855, \mathrm{p}<0.001$ ). Adélie penguins breeding in the South Orkney Islands, South Shetland Islands, and eastern AP shared similar eggshell $\delta^{15} \mathrm{~N}$ and $\delta^{13} \mathrm{C}$ values, and these were lower than the isotopic values of eggshells from Adélie penguins breeding in the western AP (Fig. 2a). While it showed statistical significance, discriminant analysis based on $\delta^{15} \mathrm{~N}$ and $\delta^{13} \mathrm{C}$ values did a poor job of differentiating between eggshells of Adélie penguin breeding in the 4 sampled regions (Wilks' lambda $=0.574, \chi^{2}=$ 104.756, df $=6, \mathrm{p}<0.001$ ). Overall correct assignment after jackknife validation was $47.2 \%$ (Fig. 3a; 26.7, $66.7,20.3$, and $78.4 \%$ for eggshells from the South Orkney Islands, South Shetland Islands, eastern AP, and western AP, respectively). However, eggshell isotopic values were much better at discriminating between northern (South Orkney Islands, South Shetlands, and eastern AP) and southern (western AP) breeding colonies (Wilks' lambda $=0.596, \chi^{2}=98.44$, df $=2, \mathrm{p}<0.001$ ). Overall correct assignment after jackknife validation was $79.8 \%$ (Fig. $3 c_{;} ; 7.3 \%$ of the northern group and $81.8 \%$ of the southern group).

While there was some variation in the isotopic signatures of gentoo penguin eggshells at the breeding colony level, differences within and across regions in $\delta^{15} \mathrm{~N}$ and $\delta^{13} \mathrm{C}$ values were less common relative to the differences observed in Adélie penguins (Table 3 ; $\delta^{15} \mathrm{~N}: F_{12,182}=10.388, \mathrm{p}<0.001 ; \delta^{13} \mathrm{C}: F_{12,182}=16.362$, $\mathrm{p}<0.001$ ). Gentoo penguin eggshell $\delta^{15} \mathrm{~N}$ values did not differ across regions, while eggshell $\delta^{13} \mathrm{C}$ values in gentoo penguins breeding in the eastern AP were lower than those breeding in the South Shetland Islands and the western AP (Fig. 2b). Similarly, while it showed statistical significance, discriminant analysis based on $\delta^{15} \mathrm{~N}$ and $\delta^{13} \mathrm{C}$ values did a poor job of differentiating between eggshells of gentoo penguins breeding in the 3 sampled regions (Wilks' lambda $=$ $0.763, \chi^{2}=48.206, \mathrm{df}=4, \mathrm{p}<0.001$ ). Correct assignment after jackknife validation was $54.9 \%$ (Fig. 3b; 46.6, 78.6, and $60.0 \%$ for eggshells from the South Shetland Islands, eastern AP, and western AP, respectively). However, eggshell isotopic values were much better at discriminating between gentoo penguin colonies on the eastern and western (including the South Shetland Islands) sides of the AP (Wilks'
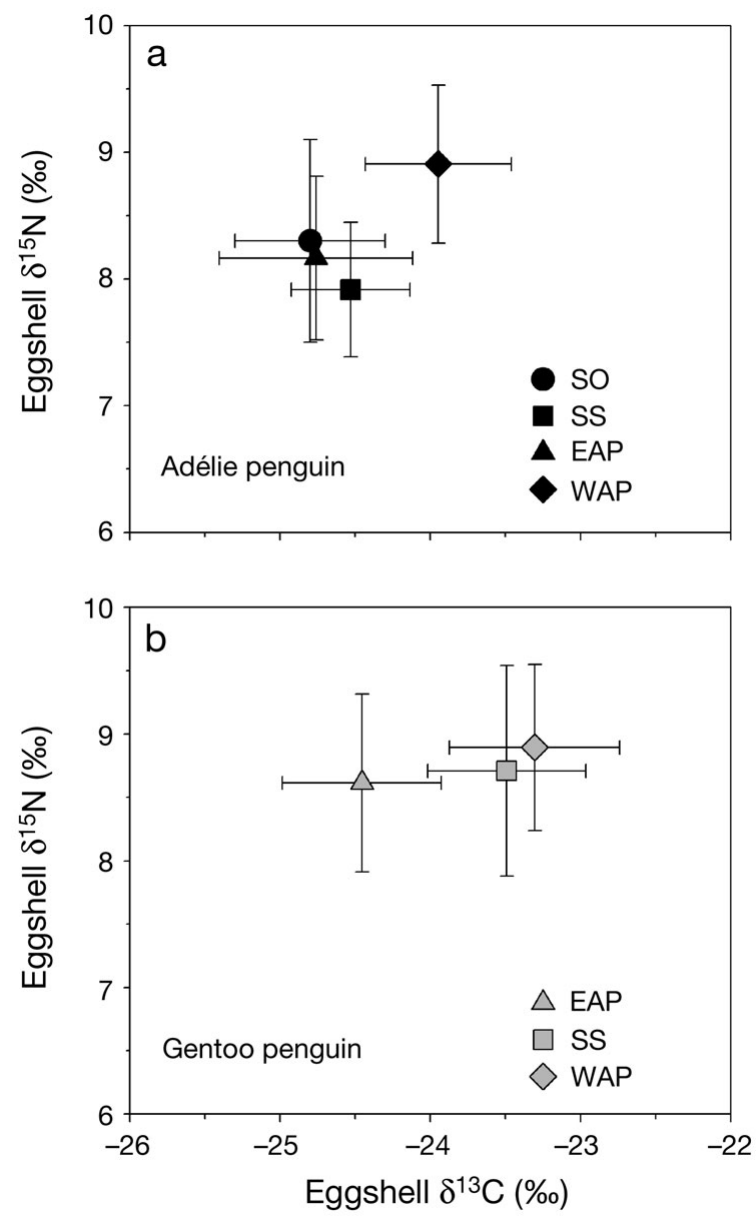

Fig. 2. Pygoscelis adeliae and P. papua. $\delta^{15} \mathrm{~N}$ and $\delta^{13} \mathrm{C}$ concentrations of (a) Adélie and (b) gentoo penguin eggshells collected from breeding colonies in the South Orkney Islands (SO), South Shetland Islands (SS), eastern Antarctic Peninsula (EAP), and western Antarctic Peninsula (WAP) during austral summer of 2006-07. Error bars represent SD 

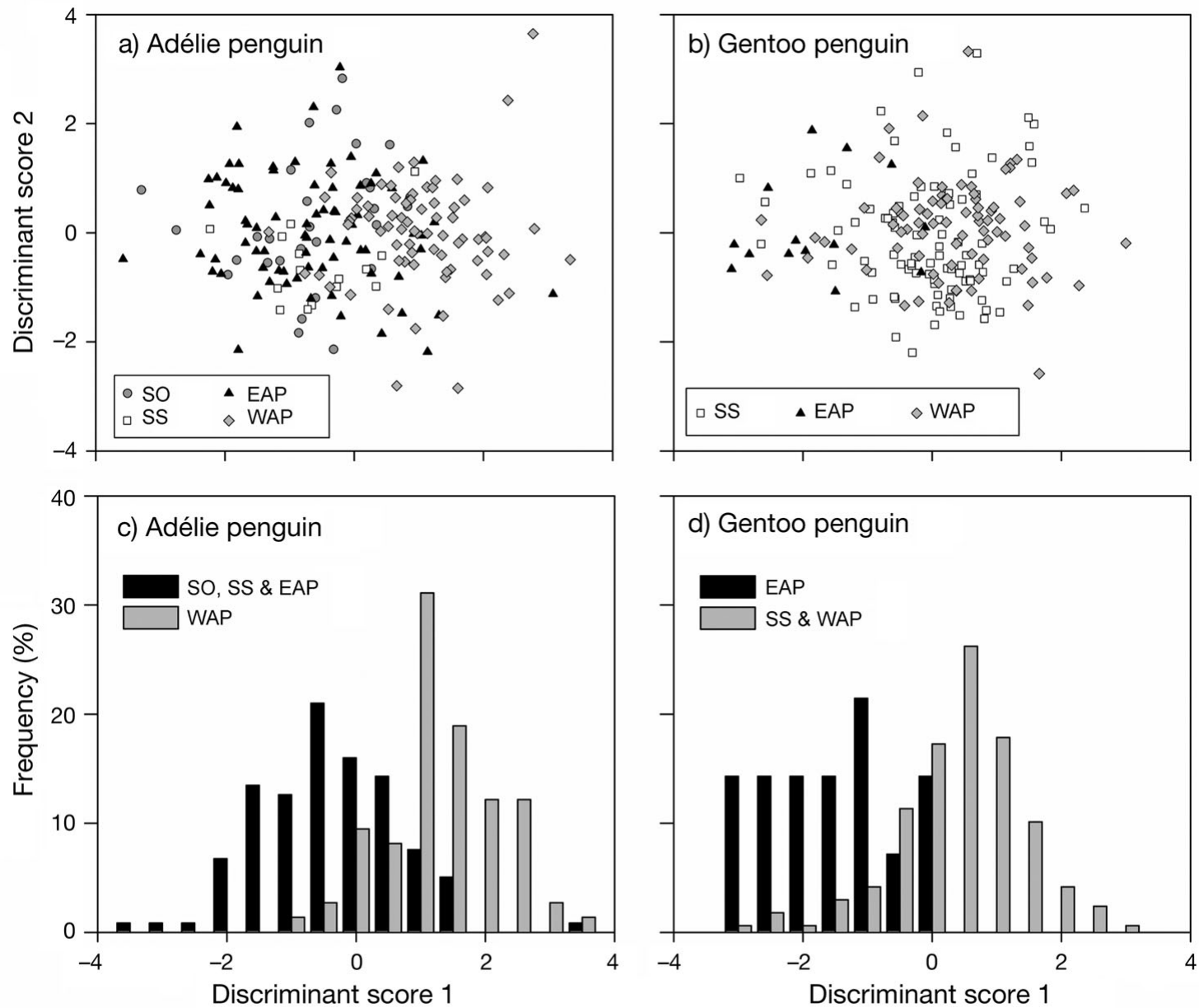

Fig. 3. Pygoscelis adeliae and P. papua. Discriminant analyses on the $\delta^{15} \mathrm{~N}$ and $\delta^{13} \mathrm{C}$ values of eggshells collected from breeding colonies in the South Orkney Islands (SO), South Shetland Islands (SS), eastern Antarctic Peninsula (EAP), and western Antarctic Peninsula (WAP) during austral summer of 2006-07. Scatter plot of the 2 resulting discriminant functions for (a) Adélie and (b) gentoo penguin eggshells. Histograms of the single resulting discriminant function for (c) Adélie penguin eggshells from northern (SO,

SS, EAP) and southern (WAP) regions and (d) gentoo penguin eggshells from eastern (EAP) and western (SS, WAP) regions

Table 1. Pygoscelis adeliae and P. papua. C:N ratio and $\delta^{15} \mathrm{~N}$ and $\delta^{13} \mathrm{C}$ concentrations (mean $\pm \mathrm{SD}$ ) of eggshells collected from breeding colonies in 4 regions during austral summer of 2006-07. Groups that do not share at least 1 superscripted letter within a column are significantly different for the variable in question at the 0.05 level. n: no. of eggshells

\begin{tabular}{|lcccc|}
\hline Region, species & $\mathrm{n}$ & $\mathrm{C}: \mathrm{N}$ & $\delta^{15} \mathrm{~N}(\% \mathrm{o})$ & $\delta^{13} \mathrm{C}(\%)$ \\
\hline $\begin{array}{l}\text { South Orkney Islands } \\
\text { Adélie penguin }\end{array}$ & 30 & $3.8 \pm 0.1$ & $8.3 \pm 0.8^{\mathrm{a}, \mathrm{b}}$ & $-24.8 \pm 0.5^{\mathrm{a}}$ \\
$\begin{array}{l}\text { South Shetland Islands } \\
\text { Adélie penguin }\end{array}$ & 15 & $3.7 \pm 0.2$ & $7.9 \pm 0.5^{\mathrm{a}}$ & $-24.5 \pm 0.4^{\mathrm{a}}$ \\
$\begin{array}{l}\text { Gentoo penguin } \\
\text { Eastern Antarctic Peninsula }\end{array}$ & 88 & $3.8 \pm 0.2$ & $8.7 \pm 0.8^{\mathrm{b}, \mathrm{c}}$ & $-23.5 \pm 0.5^{\mathrm{b}}$ \\
$\begin{array}{l}\text { Adélie penguin } \\
\text { Gentoo penguin }\end{array}$ & 74 & $3.7 \pm 0.3$ & $8.2 \pm 0.6^{\mathrm{a}}$ & $-24.8 \pm 0.6^{\mathrm{a}}$ \\
$\begin{array}{l}\text { Western Antarctic Peninsula } \\
\text { Adélie penguin }\end{array}$ & 14 & $3.8 \pm 0.1$ & $8.6 \pm 0.7^{\mathrm{a}, \mathrm{b}, \mathrm{c}}$ & $-24.5 \pm 0.5^{\mathrm{a}}$ \\
Gentoo penguin & 74 & $3.6 \pm 0.2$ & $8.9 \pm 0.6^{\mathrm{c}}$ & $-23.9 \pm 0.5^{\mathrm{c}}$ \\
\hline
\end{tabular}

lambda $=0.792, \chi^{2}=41.693, \mathrm{df}=2$, $\mathrm{p}<0.001)$. Overall correct assignment after jackknife validation was $84.6 \%$ (Fig. $3 d_{;} 78.6 \%$ of the eastern group and $85.1 \%$ of the western group).

\section{Prey items and pre-breeding diet composition}

We found significant differences across the isotopic values of common Adélie and gentoo penguin prey species (Table $4 ; \delta^{15} \mathrm{~N}: F_{2,60}=637.78, \mathrm{p}<$ $\left.0.001 ; \delta^{13} \mathrm{C}: F_{2,60}=42.98, \mathrm{p}<0.001\right)$. Post hoc Tukey comparisons determined that krill had significantly lower 
Table 2. Pygoscelis adeliae. Location, C:N ratio, and $\delta^{15} \mathrm{~N}$ and $\delta^{13} \mathrm{C}$ concentrations (mean $\pm \mathrm{SD}$ ) of eggshells collected from breeding colonies during austral summer of 2006-07. Groups that do not share at least 1 superscripted letter within a column are significantly different for the variable in question at the 0.05 level. Is. = Island; site no.: no. designating the respective site in

Fig. $1 ;$ n: no. of eggshells

\begin{tabular}{|lccccc|}
\hline Region, site (site no.) & Latitude, longitude & $\mathrm{n}$ & $\mathrm{C}: \mathrm{N}$ & $\delta^{15} \mathrm{~N}(\%)$ & $\delta^{13} \mathrm{C}(\%)$ \\
\hline South Orkney Islands & & & & & \\
Shingle Cove, Coronation Is. (1) & $60.65^{\circ} \mathrm{S}, 45.57^{\circ} \mathrm{W}$ & 15 & $3.7 \pm 0.1$ & $7.9 \pm 0.6^{\mathrm{a}}$ & $-24.7 \pm 0.4^{\mathrm{a}, \mathrm{b}}$ \\
$\begin{array}{l}\text { Gourlay Peninsula, Signy Is. (2) } \\
\text { South Shetland Islands }\end{array}$ & $60.72^{\circ} \mathrm{S}, 45.57^{\circ} \mathrm{W}$ & 15 & $3.9 \pm 0.1$ & $8.7 \pm 0.8^{\mathrm{b}, \mathrm{c}, \mathrm{d}}$ & $-24.9 \pm 0.6^{\mathrm{a}}$ \\
Admiralty Bay, King George Is. (3) & $62.17^{\circ} \mathrm{S}, 58.45^{\circ} \mathrm{W}$ & 15 & $3.4 \pm 0.1$ & $7.9 \pm 0.5^{\mathrm{a}}$ & $-24.5 \pm 0.4^{\mathrm{a}, \mathrm{b}, \mathrm{c}}$ \\
Eastern Antarctic Peninsula & & & & & \\
Tay Head, Joinville Is. (9) & $63.53^{\circ} \mathrm{S}, 56.92^{\circ} \mathrm{W}$ & 14 & $3.9 \pm 0.1$ & $8.0 \pm 0.5^{\mathrm{a}}$ & $24.4 \pm 0.7^{\mathrm{a}, \mathrm{b}, \mathrm{c}}$ \\
Brown Bluff, Tabarin Peninsula (10) & $63.35^{\circ} \mathrm{S}, 55.55^{\circ} \mathrm{W}$ & 15 & $3.8 \pm 0.2$ & $8.5 \pm 0.5^{\mathrm{a}, \mathrm{b}, \mathrm{c}}$ & $24.9 \pm 0.5^{\mathrm{a}}$ \\
Paulet Is. (11) & $63.58^{\circ} \mathrm{S}, 55.78^{\circ} \mathrm{W}$ & 15 & $3.5 \pm 0.1$ & $7.9 \pm 0.4^{\mathrm{a}}$ & $24.9 \pm 0.5^{\mathrm{a}}$ \\
Devil Is. (12) & $63.80^{\circ} \mathrm{S}, 57.28^{\circ} \mathrm{W}$ & 15 & $3.8 \pm 0.2$ & $8.4 \pm 0.8^{\mathrm{a}, \mathrm{b}, \mathrm{c}}$ & $24.7 \pm 0.5^{\mathrm{a}, \mathrm{b}}$ \\
Penguin Point, Seymour Is. (13) & $64.30^{\circ} \mathrm{S}, 56.68^{\circ} \mathrm{W}$ & 15 & $3.6 \pm 0.1$ & $8.0 \pm 0.7^{\mathrm{a}, \mathrm{b}}$ & $24.9 \pm 0.8^{\mathrm{a}}$ \\
Western Antarctic Peninsula & & & & \\
Dream Is. (15) & $64.73^{\circ} \mathrm{S}, 64.23^{\circ} \mathrm{W}$ & 14 & $3.7 \pm 0.1$ & $8.9 \pm 0.3^{\mathrm{c}, \mathrm{d}}$ & $24.1 \pm 0.5^{\mathrm{b}, \mathrm{c}, \mathrm{d}}$ \\
Torgersen Is. (16) & $64.77^{\circ} \mathrm{S}, 64.08^{\circ} \mathrm{W}$ & 15 & $3.6 \pm 0.1$ & $8.9 \pm 0.5^{\mathrm{c}, \mathrm{d}}$ & $24.0 \pm 0.5^{\mathrm{cd}}$ \\
Bisco Point, Anvers Is. (17) & $64.80^{\circ} \mathrm{S}, 63.79^{\circ} \mathrm{W}$ & 15 & $3.6 \pm 0.1$ & $8.7 \pm 0.5^{\mathrm{b}, \mathrm{c}, \mathrm{d}}$ & $24.1 \pm 0.4^{\mathrm{b}, \mathrm{c}, \mathrm{d}}$ \\
Yalour Is. (22) & $65.23^{\circ} \mathrm{S}, 64.17^{\circ} \mathrm{W}$ & 15 & $3.9 \pm 0.3$ & $9.3 \pm 0.9^{\mathrm{d}}$ & $23.9 \pm 0.4^{\mathrm{c}, \mathrm{d}}$ \\
Berthelot Is. (23) & $65.33^{\circ} \mathrm{S}, 64.15^{\circ} \mathrm{W}$ & 15 & $3.6 \pm 0.1$ & $8.7 \pm 0.5^{\mathrm{b}, \mathrm{c}, \mathrm{d}}$ & $23.7 \pm 0.4^{\mathrm{d}}$ \\
\hline
\end{tabular}

$\delta^{15} \mathrm{~N}$ and $\delta^{13} \mathrm{C}$ values relative to both fish species. The 2 fish species did not significantly differ in their $\delta^{15} \mathrm{~N}$ and $\delta^{13} \mathrm{C}$ values (Table 4 ).

Using eggshell $\delta^{15} \mathrm{~N}$ values corrected with a discrimination factor derived from a captive population of gentoo penguins, our isotopic model estimated that fish comprised a significant portion (46.8 to $62.9 \%$ ) of female Adélie and gentoo penguin diets prior to breeding (Table 5). Mixing-model estimates of the pre-breeding diets of female gentoo penguins did not differ significantly across regions (eastern AP vs. South Shetland Islands: $t=0.328$, df $=45.888, \mathrm{p}=$ 0.744; eastern AP vs. western AP: $t=0.981$, df $=$ 42.918, $p=0.332$; South Shetland Islands vs. western AP: $t=0.775, \mathrm{df}=37.357, \mathrm{p}=0.443$ ). In contrast, our results suggest that female Adélie penguins breeding in the western AP consumed a larger proportion of fish during the pre-breeding period than did Adélie penguins from the other 3 regions (Table 5; South Orkney Islands vs. western AP: $t=2.916$, df $=68.451$, $\mathrm{p}=0.005$; South Shetland Islands vs. western AP: $t=$ 5.082, df $=36.8, \mathrm{p}<0.001$; eastern AP vs. western

Table 3. Pygoscelis papua. Location, C:N ratio, and $\delta^{15} \mathrm{~N}$ and $\delta^{13} \mathrm{C}$ concentrations (mean $\pm \mathrm{SD}$ ) of eggshells collected from breeding colonies during austral summer of 2006-07. Groups that do not share at least 1 superscripted letter within a column are significantly different for the variable in question at the 0.05 level. Data for Cape Shirreff, Livingston Island are taken from Polito et al. (2009). Is. = Island; site no.: no. designating the respective site in Fig. 1 ; n: no. of eggshells

\begin{tabular}{|lccccc}
\hline Region, site (site no.) & Latitude, longitude & $\mathrm{n}$ & $\mathrm{C}: \mathrm{N}$ & $\delta^{15} \mathrm{~N}(\%)$ & $\delta^{13} \mathrm{C}(\%)$ \\
\hline South Shetland Islands & & & & & \\
Admiralty Bay, King George Is. (3) & $62.17^{\circ} \mathrm{S}, 58.45^{\circ} \mathrm{W}$ & 15 & $3.8 \pm 0.1$ & $8.4 \pm 0.5^{\mathrm{a}, \mathrm{b}}$ & $-24.1 \pm 0.6^{\mathrm{a}}$ \\
Ardley Is., King George Is. (4) & $62.22^{\circ} \mathrm{S}, 58.93^{\circ} \mathrm{W}$ & 15 & $3.9 \pm 0.1$ & $8.6 \pm 0.5^{\mathrm{a}, \mathrm{b}, \mathrm{c}}$ & $-23.4 \pm 0.4^{\mathrm{b}, \mathrm{c}}$ \\
Barton Peninsula, King George Is. (5) & $62.24^{\circ} \mathrm{S}, 58.78^{\circ} \mathrm{W}$ & 15 & $3.8 \pm 0.1$ & $8.6 \pm 0.6^{\mathrm{a}, \mathrm{b}, \mathrm{c}}$ & $-23.2 \pm 0.4^{\mathrm{c}, \mathrm{d}}$ \\
Potter Peninsula, King George Is. (6) & $62.25^{\circ} \mathrm{S}, 58.65^{\circ} \mathrm{W}$ & 8 & $4.0 \pm 0.1$ & $8.7 \pm 0.4^{\mathrm{a}, \mathrm{b}, \mathrm{c}}$ & $-23.1 \pm 0.5^{\mathrm{c}, \mathrm{d}}$ \\
Barrentos Is., Aitcho Is. (7) & $62.41^{\circ} \mathrm{S}, 59.75^{\circ} \mathrm{W}$ & 15 & $3.8 \pm 0.3$ & $10.0 \pm 0.6^{\mathrm{d}}$ & $-23.5 \pm 0.5^{\mathrm{b}, \mathrm{c}}$ \\
Cape Shirreff, Livingston Is. (8) & $62.47^{\circ} \mathrm{S}, 60.78^{\circ} \mathrm{W}$ & 20 & $3.7 \pm 0.3$ & $8.2 \pm 0.6^{\mathrm{a}}$ & $-23.4 \pm 0.3^{\mathrm{b}, \mathrm{c}}$ \\
Eastern Antarctic Peninsula & & & & \\
Brown Bluff, Tabarin Peninsula (10) & $63.35^{\circ} \mathrm{S}, 55.55^{\circ} \mathrm{W}$ & 14 & $3.8 \pm 0.1$ & $8.6 \pm 0.7^{\mathrm{a}, \mathrm{b}, \mathrm{c}}$ & $-24.5 \pm 0.5^{\mathrm{a}}$ \\
Western Antarctic Peninsula & & & & & \\
Cuverville Is. (14) & $64.68^{\circ} \mathrm{S}, 62.63^{\circ} \mathrm{W}$ & 15 & $3.9 \pm 0.1$ & $8.5 \pm 0.4^{\mathrm{a}, \mathrm{b}, \mathrm{c}}$ & $-23.9 \pm 0.5^{\mathrm{a}, \mathrm{b}}$ \\
Bisco Point, Anvers Is. (17) & $64.80^{\circ} \mathrm{S}, 63.79^{\circ} \mathrm{W}$ & 9 & $4.0 \pm 0.1$ & $9.2 \pm 0.5^{\mathrm{b}, \mathrm{c}}$ & $-23.5 \pm 0.3^{\mathrm{b}, \mathrm{c}}$ \\
Jougla Point, Wiencke Is. (18) & $64.82^{\circ} \mathrm{S}, 63.50^{\circ} \mathrm{W}$ & 11 & $4.0 \pm 0.3$ & $8.5 \pm 0.5^{\mathrm{a}, \mathrm{b}}$ & $-23.4 \pm 0.5^{\mathrm{b}, \mathrm{c}}$ \\
Neko Harbour, Andvord Bay (19) & $64.83^{\circ} \mathrm{S}, 62.55^{\circ} \mathrm{W}$ & 15 & $3.9 \pm 0.2$ & $9.1 \pm 0.8^{\mathrm{b}_{,} \mathrm{c}}$ & $-23.2 \pm 0.3^{\mathrm{c}, \mathrm{d}}$ \\
Pleneau Is. (20) & $65.10^{\circ} \mathrm{S}, 64.07^{\circ} \mathrm{W}$ & 15 & $3.8 \pm 0.1$ & $8.8 \pm 0.6^{\mathrm{a}, \mathrm{b}, \mathrm{c}}$ & $-22.7 \pm 0.5^{\mathrm{d}}$ \\
Petermann Is. (21) & $65.17^{\circ} \mathrm{S}, 64.17^{\circ} \mathrm{W}$ & 15 & $3.8 \pm 0.1$ & $9.3 \pm 0.6^{\mathrm{c}, \mathrm{d}}$ & $-23.2 \pm 0.3^{\mathrm{c}}$ \\
\hline
\end{tabular}


Table 4. C:N ratio and $\delta^{15} \mathrm{~N}$ and $\delta^{13} \mathrm{C}$ concentrations (mean $\pm \mathrm{SD}$ ) of common Adélie and gentoo penguin prey species collected during trawls conducted in the vicinity of the Antarctic Peninsula, South Shetland Islands, and South Orkney Islands during the austral summers of 2005-06 to 2008-09. Groups that do not share at least 1 superscripted letter within a column are significantly different for the variable in question at the 0.05 level

\begin{tabular}{|lcccc|}
\hline Prey type, species & $\mathrm{n}$ & $\mathrm{C}: \mathrm{N}$ & $\delta^{15} \mathrm{~N}(\%)$ & $\delta^{13} \mathrm{C}(\%)$ \\
\hline $\begin{array}{l}\text { Krill } \\
\begin{array}{l}\text { Euphausia superba } \\
\text { Fish }\end{array}\end{array}$ & 20 & $3.7 \pm 0.2$ & $3.2 \pm 0.7^{\mathrm{a}}$ & $-26.2 \pm 0.9^{\mathrm{a}}$ \\
$\begin{array}{l}\text { Pleuragramma antarcticum } \\
\text { Lepidonotothen squamifrons }\end{array}$ & 10 & $3.4 \pm 0.2$ & $9.4 \pm 0.5^{\mathrm{b}}$ & $-24.7 \pm 0.4^{\mathrm{b}}$ \\
\hline
\end{tabular}

AP: $t=4.331$, df $=159.971, \mathrm{p}<0.001)$. Furthermore, the results of our sensitivity analysis suggest that our estimates of the pre-breeding diets of female Adélie and gentoo penguins would change by 15.6 to $16.2 \%$ per $1 \%$ deviation from our assumed $\delta^{15} \mathrm{~N}$ discrimination factor of $+1.8 \%$ o (Fig. 4 ).

\section{DISCUSSION}

\section{Habitat use prior to breeding}

During the breeding season, the foraging ranges of Adélie and gentoo penguins are restricted to areas near their colonies $(<100 \mathrm{~km})$ due to the need to return regularly for incubation and chick-feeding duties (Trivelpiece et al. 1987, Clarke et al. 2006). During this time, Adélie penguins are generally shallow divers and forage in offshore, pelagic habitats, while gentoo penguins are found closer inshore, diving relatively deeper to forage in benthic habitats (Trivelpiece et al. 1987, Miller et al. 2009, Kokubun et al. 2010, Wilson
2010). We found that, in general, gentoo penguins had higher eggshell $\delta^{13} \mathrm{C}$ values than Adélie penguins. Benthic and inshore marine food webs are more enriched in ${ }^{13} \mathrm{C}$ than pelagic and offshore food webs due to differences in carbon sources between the 2 habitats (benthic macro-algae vs. pelagic phytoplankton; France 1995, Dunton 2001). Our results suggest that, similar to during the breeding season, prior to breeding, female gentoo penguins feed more often in inshore, benthic habitats than Adélie penguins. These results agree with previous observations that Adélie penguins inhabit the pack ice during winter, while gentoo penguins forage in open-water, near-shore habitats and remain close $(<250 \mathrm{~km})$ to their breeding colonies (Fraser et al. 1992, Wilson et al. 1998, Clausen \& Pütz 2003, Tanton et al. 2004).

A possible exception to this generalization can be seen in the eastern AP, where eggshell $\delta^{13} \mathrm{C}$ values did not differ between species. The single gentoo penguin colony sampled in the eastern AP (Brown Bluff, Tabarin Peninsula; Fig. 1) lies within Antarctic Sound, where many large tabular icebergs flowing westward from the Weddell Sea become grounded (Barker et al. 2007, M. Polito pers. obs.). Female gentoo penguins at Brown Bluff may be foraging more in pelagic habitats relative to gentoo penguins in other regions and/or $\delta^{13} \mathrm{C}$ values may be lower in this region due to a reduction in benthic foraging habitats due to iceberg scour (Barnes 1999, Gerdes et al. 2003). While there may be regional variability in the types of foraging habitats used prior to breeding, it is likely that gentoo penguins in the AP generally forage in near-shore habitats.

Table 5. Pygoscelis adeliae and P. papua. Predicted diet compositions (mean \pm SE) and $95 \%$ confidence intervals (CI) of females during the pre-breeding period based on stable isotope analysis of eggshells collected from breeding colonies in 4 regions during austral summer of 2006-07. Estimates use the single isotope $\left(\delta^{15} \mathrm{~N}\right), 2$-source (krill and fish) mixing model described by Phillips \& Gregg (2001), with eggshell $\delta^{15} \mathrm{~N}$ values corrected for isotopic discrimination (+1.8\%; Polito et al. 2009). Groups that do not share at least 1 superscripted letter within a column are significantly different for the variable in question at the 0.05 level

\begin{tabular}{|c|c|c|c|c|c|}
\hline \multirow{2}{*}{ Region, species } & \multirow[t]{2}{*}{$\mathrm{n}$} & \multicolumn{4}{|c|}{ - Female pre-breeding diet composition (\%) } \\
\hline & & Krill & $95 \% \mathrm{CI}$ & Fish & $95 \% \mathrm{CI}$ \\
\hline \multicolumn{6}{|c|}{ South Orkney Islands } \\
\hline Adélie penguin & 30 & $46.8 \pm 2.7^{\mathrm{a}, \mathrm{b}, \mathrm{c}}$ & $41.2-52.3$ & $53.2 \pm 2.7^{\mathrm{a}, \mathrm{b}, \mathrm{c}}$ & $47.7-58.8$ \\
\hline \multicolumn{6}{|c|}{ South Shetland Islands } \\
\hline Adélie penguin & 15 & $53.2 \pm 2.6^{\mathrm{a}}$ & $48.0-58.5$ & $46.8 \pm 2.6^{\mathrm{a}}$ & $41.5-52.0$ \\
\hline Gentoo penguin & 88 & $42.2 \pm 2.8^{\mathrm{b}, \mathrm{c}, \mathrm{d}}$ & $36.3-48.1$ & $57.8 \pm 2.8^{\mathrm{b}, \mathrm{c}, \mathrm{d}}$ & $51.9-63.7$ \\
\hline \multicolumn{6}{|c|}{ Eastern Antarctic Peninsula } \\
\hline Adélie penguin & 74 & $48.4 \pm 1.8^{\mathrm{a}, \mathrm{b}}$ & $44.7-52.0$ & $51.6 \pm 1.8^{\mathrm{a}, \mathrm{b}}$ & $48.0-55.3$ \\
\hline Gentoo penguin & 14 & $43.8 \pm 3.8^{\mathrm{b}, \mathrm{c}, \mathrm{d}}$ & $35.9-51.6$ & $56.3 \pm 3.8^{\mathrm{b}, \mathrm{c}, \mathrm{d}}$ & $48.4-64.1$ \\
\hline \multicolumn{6}{|c|}{ Western Antarctic Peninsula } \\
\hline Adélie penguin & 74 & $37.1 \pm 1.9^{\mathrm{d}}$ & $33.4-40.8$ & $62.9 \pm 1.9^{d}$ & $59.2-66.6$ \\
\hline Gentoo penguin & 80 & $39.1 \pm 2.9^{\mathrm{c}, \mathrm{d}}$ & $33.0-45.1$ & $60.9 \pm 2.9^{\mathrm{c}, \mathrm{d}}$ & $54.9-67.0$ \\
\hline
\end{tabular}




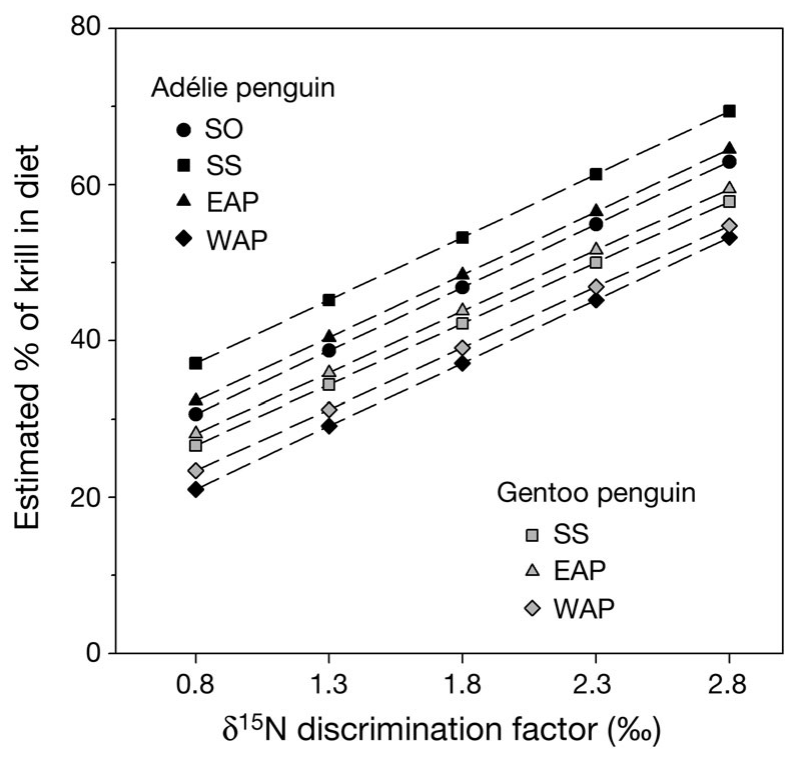

Fig. 4. Pygoscelis adeliae and P. papua. The effect of variation in $\delta^{15} \mathrm{~N}$ discrimination factor on the estimated diet composition (\% of krill in diet) of females during the pre-breeding period based on stable isotope analysis of eggshells collected from breeding colonies in the South Orkney Islands (SO), South Shetland Islands (SS), eastern Antarctic Peninsula (EAP), and western Antarctic Peninsula (WAP) during austral summer of 2006-07. Estimates use the single isotope $\left(\delta^{15} \mathrm{~N}\right)$, 2 -source (krill and fish) mixing model described by Phillips \& Gregg (2001). A $\delta^{15} \mathrm{~N}$ discrimination factor of $+1.8 \%$ represents the value derived from a controlled dietary study of a captive population of gentoo penguins (Polito et al. 2009)

Therefore, variations in the stable isotope values of gentoo penguin eggshells within and across regions probably reflect local scale variation in the environmental conditions of their near-shore foraging grounds.

\section{Distribution prior to breeding and the Adélie gap}

In addition to delineating vertical trends (benthic vs. pelagic), natural isotopic patterns in the marine environment can infer the geographic origin of animal diets (reviewed in Hobson 1999). In the Southern Ocean, the $\delta^{13} \mathrm{C}$ values of particulate organic matter track transitions between water mass sources defined by frontal zones and other oceanographic features with isotopic trends propagated up the food chain (Cherel \& Hobson 2007, Phillips et al. 2009, Quillfeldt et al. 2010). When examining Adélie penguins breeding in the AP, we found that the isotopic signatures of their eggshells divided female penguins into 2 discrete groups: one north of the Adélie gap, comprised of breeding colonies in the South Orkney Islands, South Shetland Islands, and eastern AP, and the other south of the Adélie gap, comprised of breeding colonies in the western AP. As shipboard survey data have shown that Adélie penguins are found almost exclusively in the pack ice outside of the breeding season, the observed isotopic differentiation between these 2 groups likely implies differences in their geographic location prior to breeding, rather than habitat type per se (Fraser et al. 1992, Chapman et al. 2004, Ribic et al. 2008). In addition, eggshells from breeding colonies to the south of the Adélie gap had higher $\delta^{13} \mathrm{C}$ values than those to the north. As the $\delta^{13} \mathrm{C}$ signatures of pelagic primary producers are higher in the Bellingshausen Sea relative to the Weddell Sea (Quillfeldt et al. 2010), our isotopic analyses provide support for the hypothesis that Adélie penguins that breed to the south of the Adélie gap (Anvers Island to the south along the western AP) winter in the Bellingshausen Sea and those that breed to the north of the Adélie gap (South Orkney Islands, South Shetland Islands, and eastern AP) winter in the Weddell Sea (Fraser et al. 1992, Fraser \& Trivelpiece 1996, Trivelpiece \& Fraser 1996).

Studies of Adélie penguins using devices such as satellite transmitters, GPS, and other data loggers suggest that after breeding, adults can travel as far as $17000 \mathrm{~km}$ (though more commonly 1000 to $2000 \mathrm{~km}$ ) away from their breeding colonies to reach the packice zone where they overwinter (Kerry et al. 1995, Davis et al. 1996, 2001, Clarke et al. 2003, Ballard et al. 2010). In the AP region, recent tracking studies also provide support for our hypothesis of a common wintering range in the Weddell Sea for the 3 geographically disjunct Adélie penguin breeding groups found to the north of the Adélie gap. Dunn et al. (in press) tracked the winter movement of Adélie penguin breeding at Signy Island, South Orkney Islands and found that adults travel as far as $1300 \mathrm{~km}$ away from their breeding colony to winter in the pack ice of the Weddell Sea. In addition, adult Adélie penguins breeding on King George Island, South Shetland Islands, have been tracked to the pack ice in the eastern Weddell Sea, where they molt (W. Trivelpiece unpubl. data). Unfortunately, to our knowledge no published studies have documented winter movements of Adélie penguins breeding in colonies along the eastern or western AP. While tracking studies can provide detailed distributional data, small sample sizes and limited spatial (number of breeding colonies) and temporal (duration of tracking) scales make it difficult to extrapolate penguin distributional data at the population level. The present study highlights how the stable isotope analysis of penguin tissues can be used to confirm distributional trends identified by tracking and shipboard studies on a regional scale. 


\section{Diet prior to breeding}

Most dietary studies of Adélie and gentoo penguins use stomach content analysis to examine diet composition during the chick-rearing period, when adults bring food ashore for their chicks. Studies in the AP suggest that during the breeding season, the diets of both species are often dominated by krill (when measured as wet mass), but that gentoo penguins also commonly consume fish (Trivelpiece et al. 1987, Lynnes et al. 2004, Miller et al. 2009). In contrast, our results suggest that high trophic-level prey such as fish comprised a significant portion (46.8 to $62.9 \%$ ) of both female Adélie and gentoo penguin diets prior to breeding. This result agrees with the few existing studies of winter diets of Adélie and gentoo penguins in the AP region, which have found fish and squid to be important prey items for both species (Jablonski 1985, Ainley et al. 1992, Coria et al. 2000). While only the contributions of krill versus fish in penguin diets were assessed in our mixing-model analyses, it is important to note that as the fish and squid species consumed by Pygoscelis spp. penguins often have similar $\delta^{15} \mathrm{~N}$ values, the estimated fish portion of female penguins' prebreeding diets likely represent the dietary contribution of all high trophic-level prey species such as fish and/or squid (Quillfeldt et al. 2005, Cherel 2008, M. Polito unpubl. data).

During the breeding season, gentoo penguins in the AP generally consume a relatively higher proportion of fish than Adélie penguins (Trivelpiece et al. 1987, Miller et al. 2009). However, inter-specific comparisons of diets prior to breeding are less clear. Overall mean gentoo penguin eggshell $\delta^{15} \mathrm{~N}$ values were higher than Adélie penguin values, and the range of $\delta^{15} \mathrm{~N}$ values observed at the breeding colony level was also higher in gentoo (8.4 to $10.0 \%$ ) than Adélie penguins ( 7.9 to $9.3 \%$ ). This result implies a relatively larger contribution of high trophic-level prey such as fish in gentoo penguin diets prior to breeding. However, when examining $\delta^{15} \mathrm{~N}$ values within regions, with the exception of the South Shetland Islands, $\delta^{15} \mathrm{~N}$ values did not vary by species. Furthermore, while mixing-model estimates of the proportion of fish (relative to krill) was generally higher in gentoo penguin diets, in some cases 95\% confidence intervals overlapped between species (Table 5). These findings indicate that while gentoo penguins often consume a relatively higher proportion of fish than Adélie penguins prior to breeding, local and regional scale factors are also important determinants of pre-breeding diets.

Researchers have hypothesized that recent reductions in both krill recruitment and abundance affect Adélie and gentoo penguins differently, with the more krill-dependent Adélie penguins expected to be at a relative disadvantage (Fraser et al. 1992, Smith et al. 1999, Forcada et al. 2006, Hinke et al. 2007). In addition, due to the similar breeding success of these 2 species, it has been hypothesized that their contrasting population trends are driven by factors operating outside the breeding season (Hinke et al. 2007, Carlini et al. 2009, Lynch et al. 2010). We found that the prebreeding diets of female Adélie penguins in the AP, in contrast to diets during the breeding season, commonly included a large percentage of high trophiclevel prey such as fish and/or squid. It is possible that seasonal shifts in the consumption of krill and fish and/or squid by Pygoscelis spp. penguins may be a reflection of the relative availability of these prey species in the marine environment. For example, a recent study examining Adélie penguin eggshells found compelling isotopic evidence of a shift from fish to krill in past penguin diets in conjunction with a proposed 'krill surplus' following the extensive harvest of whales and seals in the Southern Ocean (Emslie \& Patterson 2007). Therefore, the reduced amount of krill and higher consumption of fish and/or squid in pre-breeding diets relative to the breeding season may be a reflection of the lower krill biomass available to penguins outside of the breeding season (Lascara et al. 1999).

\section{Isotopic mixing model and discrimination factors}

Isotopic mixing models are commonly used to determine the relative contribution of multiple food sources to animal diets in marine systems (Hammill et al. 2005, Becker et al. 2007, Navarro et al. 2009, Alves-Stanley et al. 2010). However, to our knowledge, other than a preliminary analysis of a portion of our own dataset (Polito et al. 2009), only one other study has used isotopic mixing-model procedures to estimate the diet composition of wild Pygoscelis spp. penguins. Tierney et al. (2008) compared mixing-model estimates of penguin diets based on the isotopic value of Adélie penguin chick blood to adult stomach contents collected during the chick-rearing period and found that these 2 methods provide similar estimates of penguin diets at a broad taxonomic level (i.e. krill vs. fish). Unfortunately, as stomach content analysis is often logistically impossible during the pre-breeding period, we do not have comparable data against which to validate our estimates of female pre-breeding diets, as done by Tierney et al. (2008).

Isotopic mixing models are based on geometric procedures that reconstruct animal diets based on the isotopic value of each food source after correcting for isotopic discrimination (the differences in isotopic ratios between food items and consumer tissues; Phillips \& Gregg 2001, 2003, Post 2002, Caut et al. 
2008b). Much of the uncertainty involved in the use of these methods derives from the selection of an appropriate discrimination factor, as models can be sensitive to variations in these values (Post 2002, Caut et al. $2008 b)$. When estimating the composition of female Adélie and gentoo penguin diets prior to breeding, we corrected eggshell $\delta^{15} \mathrm{~N}$ values for dietary isotopic fractionation using a discrimination factor of $+1.8 \%$ derived from a captive population of gentoo penguins (Polito et al. 2009). Eggshell $\delta^{15} \mathrm{~N}$ discrimination factors have only been quantified in 2 other avian species, quail and ostrich, with discrimination factors estimated at $+1.0 \%$ o to $+3.0 \%$, respectively (Johnson 1995, Johnson et al. 1998). In addition to species-specific variation, other factors such as differences in physiological condition and the protein quality of diets between captive and wild populations could also bias discrimination factors and affect the accuracy of dietary reconstructions using isotopic mixing models (Hobson et al. 1993, Cherel et al. 2005a, Robbins et al. 2010).

It is for these reasons that we performed a sensitivity analysis to examine how resilient our estimates of female pre-breeding diets might be to variations in isotopic discrimination factors. We found that a $1 \%$ deviation in $\delta^{15} \mathrm{~N}$ discrimination factors resulted in a 15.6 to $16.2 \%$ change in our dietary estimates. Using an eggshell $\delta^{15} \mathrm{~N}$ discrimination factor near the upper limit of what has been described in previous studies $(+2.8 \%$ ) , fish comprised between 30.6 and $46.8 \%$ of estimated diet composition (Fig. 4). Our model results suggest that it would take a $\delta^{15} \mathrm{~N}$ discrimination factor $>5.0 \%$ to result in an estimated diet composition that was comprised solely of krill. As this figure is well outside the range of eggshell discrimination factors currently described (reviewed in Polito et al. 2009), these findings, along with the few existing studies of winter diets, help to support our conclusion that high trophiclevel prey such as fish and/or squid are important components of female Adélie and gentoo penguin diets prior to breeding.

\section{CONCLUSIONS}

The present study highlights the use of stable isotope analysis to provide insight into the diets and foraging habitats of female Adélie and gentoo penguins prior to breeding. Our results indicate that pre-breeding gentoo penguins feed more in benthic, inshore habitats relative to Adélie penguins, similar to differences ob. served during the chick-rearing period. However, unlike the breeding period when krill can dominate penguin diets, fish and/or other high trophic-level prey species comprise a significant portion of both female Adélie and gentoo penguin pre-breeding diets.
Finally, our findings confirm that Adélie penguin populations that are geographically separated during the breeding season by the Adélie gap also inhabit geographically distinct habitats prior to breeding. While our study examined the pre-breeding foraging ecology of Adélie and gentoo penguins over a large spatial scale, it is important to note the study's temporal limitations, as samples were collected during a single breeding season. Further work examining the isotopic signatures of eggshell is warranted to investigate how inter-annual variation in the pre-breeding diets and foraging habitats of Adélie and gentoo penguins may relate to breeding populations.

Acknowledgements. This research was funded by US National Science Foundation (NSF) Office of Polar Programs (OPP) grants ANT-0125098 and ANT-0739575. For their assistance with the collection of eggshell samples, we thank L. Blight, I. Bullock, J. Carlson, R. Dagit, M. Drennan, S. Forrest, M. McOscar, T. Mueller, and E. Woehler from Oceanites; W. Trivelpiece, S. Trivelpiece, A. Miller, R. Orben, S. Chisolm, D. Loomis, A. Loomis, S. Kropidlowski, N. Bargmann, and S. Woods from the US AMLR program; H.-U. Ulrich and A. Fröhlich from the Friedrich Schiller University of Jena; W. Fraser, K. Gorman, and J. Blum from the Polar Oceans Research Group; and D. Briggs and M. Dunn from the British Antarctic Survey. We thank M. Goebel, C. Jones, T. Near, J. Gaffney, and A. VanCise for access to krill and fish samples. M. Rider, Raytheon Polar Services, Linblad Expeditions, National Geographic and the expedition leaders, naturalists, officers, and crew of the 'National Geographic Endeavour' provided invaluable logistical support. J. Seminoff, C. Tobias, K. Durenberger, E. Unger, A. Hydrusko, and E. Guber provided helpful assistance with lipid extractions and stable isotope analysis. We thank A. Satake and 3 anonymous reviewers who provided helpful revisions to this manuscript. This work complies with, and was completed in accordance with, Antarctic Conservation Acts permits provided to S.D.E. (2006-001) and R.N. (2005-005) by the NSF.

\section{LITERATURE CITED}

Ainley DG, Ribic CA, Fraser WR (1992) Does prey preference affect habitat choice in Antarctic seabirds? Mar Ecol Prog Ser 90:207-221

Ainley DG, Ballard G, Barton KJ, Karl BJ, Rau GH, Ribic CA, Wilson PR (2003) Spatial and temporal variation of diet within a presumed metapopulation of Adélie penguins. Condor 105:95-106

> Alves-Stanley CD, Worthy GAJ, Bonde RK (2010) Feeding preferences of West Indian manatees in Florida, Belize, and Puerto Rico as indicated by stable isotope analysis. Mar Ecol Prog Ser 402:255-267

Astheimer LB, Grau CR (1985) The timing and energetic consequences of egg formation in the Adélie penguin. Condor 87:256-268

Ballard G, Toniolo V, Ainley DG, Parkinson CL, Arrigo KR, Trathan FN (2010) Responding to climate change: Adélie penguins confront astronomical and ocean boundaries. Ecology 91:2056-2069

Barker PF, Filippelli GM, Florindo F, Martin EE, Scher HD (2007) Onset and role of the Antarctic circumpolar current. Deep-Sea Res II 54:2388-2398 
Barnes DKA (1999) The influence of ice on polar nearshore benthos. J Mar Biol Assoc UK 79:401-407

> Becker BH, Peery MZ, Beissinger SR (2007) Ocean climate and prey availability affect the trophic level and reproductive success of the marbled murrelet, an endangered seabird. Mar Ecol Prog Ser 329:267-279

> Carlini AR, Coria NR, Santos MM, Negrete J, Juares MA, Daneri GA (2009) Responses of Pygoscelis adeliae and P. papua populations to environmental changes at Isla 25 de Mayo (King George Island). Polar Biol 32:1427-1433

Caut S, Angulo E, Courchamp F (2008a) Discrimination factors $\left(\delta^{15} \mathrm{~N}\right.$ and $\left.\delta^{13} \mathrm{C}\right)$ in an omnivorous consumer: effect of diet isotopic ratio. Funct Ecol 22:255-263

$>$ Caut S, Angulo E, Courchamp F (2008b) Caution on isotopic model use for analyses of consumer diet. Can J Zool 86: 438-445

Chapman EW, Ribic CA, Fraser WR (2004) The distribution of seabirds and pinnipeds in Marguerite Bay and their relationship to physical features during austral winter 2001. Deep-Sea Res II 51:2261-2278

- Cherel Y (2008) Isotopic niches of emperor and Adélie penguins in Adélie Land, Antarctica. Mar Biol 154:813-821

> Cherel Y, Hobson KA (2007) Geographical variation in carbon stable isotope signatures of marine predators: a tool to investigate their foraging areas in the Southern Ocean. Mar Ecol Prog Ser 329:281-287

> Cherel Y, Hobson KA, Bailleul F, Groscolas R (2005a) Nutrition, physiology, and stable isotopes: new information from fasting and molting penguins. Ecology 86:2881-2888

> Cherel Y, Hobson KA, Hassani S (2005b) Isotopic discrimination factors between food and blood and feathers of captive penguins: implications for dietary studies in the wild. Physiol Biochem Zool 78:106-115

Cherel Y, Hobson KA, Guinet C, Vanpé C (2007) Stable isotopes document seasonal changes in trophic niches and winter foraging individual specialization in diving predators from the Southern Ocean. J Anim Ecol 76:826-836

Clarke J, Kerry K, Fowler C, Lawless R, Eberhard S, Murphy R (2003) Post-fledging and winter migration of Adélie penguins Pygoscelis adeliae in the Mawson region of East Antarctica. Mar Ecol Prog Ser 248:267-278

Clarke J, Emmerson LM, Otahal P (2006) Environmental conditions and life history constraints determine foraging range in breeding Adélie penguins. Mar Ecol Prog Ser 310:247-261

> Clausen A, Pütz K (2003) Winter diet and foraging range of gentoo penguins (Pygoscelis papua) from Kidney Cove, Falkland Islands. Polar Biol 26:32-40

Coria N, Libertelli M, Casaux R, Darrieu C (2000) Interannual variation in the autumn diet of the gentoo penguin at Laurie Island, Antarctica. Waterbirds 23:511-517

> Davis LS, Boersma PD, Court GS (1996) Satellite telemetry of the winter migration of Adélie penguins Pygoscelis adeliae. Polar Biol 16:221-225

- Davis LS, Harcourt RG, Bradshaw CJA (2001) The winter migration of Adélie penguins breeding in the Ross Sea sector of Antarctica. Polar Biol 24:593-597

Dunn MJ, Silk JR, Trathan PN (in press) Post-breeding dispersal of Adélie penguins (Pygoscelis adeliae) nesting at Signy Island, South Orkney Islands. Polar Biol doi:10. 1007/s00300-010-0870-4

> Dunton KH (2001) $\delta^{15} \mathrm{~N}$ and $\delta^{13} \mathrm{C}$ measurements of Antarctic Peninsula fauna: trophic relationships and assimilation of benthic seaweeds. Am Zool 41:99-112

Emslie SD, Patterson WP (2007) Abrupt recent shift in $\delta^{13} \mathrm{C}$ and $\delta^{15} \mathrm{~N}$ values in Adélie penguin eggshell in Antarctica. Proc Natl Acad Sci USA 104:11666-11669
Forcada J, Trathan PN, Reid K, Murphy EJ, Croxall JP (2006) Contrasting population changes in sympatric penguin species in association with climate warming. Glob Change Biol 12:411-423

- France RL (1995) Carbon-13 enrichment in benthic compared to planktonic algae: foodweb implications. Mar Ecol Prog Ser 124:307-312

Fraser W, Hofmann E (2003) A predator's perspective on causal links between climate change, physical forcing and ecosystem response. Mar Ecol Prog Ser 265:1-15

Fraser WR, Trivelpiece WZ (1996) Factors controlling the distribution of seabirds: winter-summer heterogeneity in the distribution of Adélie penguin populations. In: Ross RM, Hofmann EE, Quetin LB (eds) Foundations for ecological research west of the Antarctic Peninsula. Antarctic Research Series, Vol 70. American Geophysical Union, Washington, DC, p 257-272

> Fraser WR, Trivelpiece WZ, Ainley DG, Trivelpiece SG (1992) Increases in Antarctic penguin populations: reduced competition with whales or a loss of sea ice due to environmental warming? Polar Biol 11:525-531

- Fry B, Baltz DN, Benfield MC, Fleeger JW, Gace A, Haas HL, Quinones-Rivera ZJ (2003) Stable isotope indicators of movement and residency for brown shrimp (Farfantepenaeus aztecus) in coastal Louisiana marshscapes. Estuaries 26:82-97

Gerdes D, Hilbig B, Montiel A (2003) Impact of iceberg scouring on macrobenthic communities in the high Antarctic Weddell Sea. Polar Biol 26:295-301

> Hammill MO, Lesage V, Carter P (2005) What do harp seals eat? Comparing diet composition from different compartments of the digestive tract with diets estimated from stable isotope ratios. Can J Zool 83:1365-1372

> Hinke JT, Salwicka K, Trivelpiece SG, Watters GM, Trivelpiece WZ (2007) Divergent responses in Pygoscelis penguins reveal a common environmental driver. Oecologia 153:845-855

> Hobson KA (1995) Reconstructing avian diets using stable carbon and nitrogen isotope analysis of egg components: patterns of isotopic fractionation and turnover. Condor 97 : $752-762$

Hobson KA (1999) Tracing origins and migration of wildlife using stable isotopes: a review. Oecologia 120:314-326

Hobson KA, Alisauskas RT, Clark RG (1993) Stable-nitrogen isotope enrichment in avian tissues due to fasting and nutritional stress: implications for isotopic analyses of diet. Condor 95:388-394

Jablonski B (1985) The diet of penguins on King George Island, South Shetland Islands. Acta Zool Cracov 29: 117-186

Jacob U, Mintenbeck K, Brey T, Knust R, Beyer K (2005) Stable isotope food web studies: a case for standardized sample treatment. Mar Ecol Prog Ser 287:251-253

Johnson BJ (1995) The stable isotope biogeochemistry of ostrich eggshell and its application to late Quaternary paleoenvironmental reconstructions in South Africa. PhD dissertation, University of Colorado, Boulder

> Johnson BJ, Fogel ML, Miller GH (1998) Stable isotopes in modern ostrich eggshell: a calibration for paleoenvironmental applications in semi-arid regions of southern Africa. Geochim Cosmochim Acta 62:2451-2461

Karnovsky NJ (1997) The fish component of Pygoscelis penguin diets. MS thesis, Montana State University, Bozeman

Kerry K, Clarke J, Else G (1995) The foraging range of Adélie penguins at Béchervaise Island, MacRobertson Land, Antarctica as determined by satellite telemetry. In: Dann P, Norman I, Reilly P (eds) The penguins. Surrey Beatty \& Sons, Sydney, p 216-243 
Kokubun N, Takahashi A, Mori Y, Watanabe S, Shin HC (2010) Comparison of diving behavior and foraging habitat use between chinstrap and gentoo penguins breeding in the South Shetland Islands, Antarctica. Mar Biol 157: 811-825

Lascara CM, Hofmann EE, Ross RR, Quetin LB (1999) Seasonal variability in the distribution of Antarctic krill, Euphausia superba, west of the Antarctic Peninsula. Deep-Sea Res I 46:951-984

Lynch HJ, Naveen R, Fagan WF (2008) Censuses of penguins, blue-eyed shags, and southern giant petrel populations in the Antarctic Peninsula, 2001-2007. Mar Ornithol 36: 83-97

Lynch HJ, Fagan WF, Naveen R (2010) Population trends and reproductive success at a frequently visited penguin colony on the western Antarctic Peninsula. Polar Biol 33: 493-503

Lynnes AS, Reid K, Croxall JP (2004) Diet and reproductive success of Adélie and chinstrap penguins: linking response of predators to prey population dynamics. Polar Biol 27:544-554

Miller AK, Karnovsky NJ, Trivelpiece WZ (2009) Flexible foraging strategies of gentoo penguins Pygoscelis papua over 5 years in the South Shetland Islands, Antarctica. Mar Biol 156:2527-2537

> Navarro J, Louzao M, Igual JM, Oro D and others (2009) Seasonal changes in the diet of a critically endangered seabird and the importance of trawling discards. Mar Biol 156:2571-2578

Phillips DL, Gregg JW (2001) Uncertainty in source partitioning using stable isotopes. Oecologia 127:171-179

Phillips DL, Gregg JW (2003) Source partitioning using stable isotopes: coping with too many sources. Oecologia 136: 261-269

Phillips RA, Bearhop S, McGill RAR, Dawson DA (2009) Stable isotopes reveal individual variation in migration strategies and habitat preferences in a suite of seabirds during the nonbreeding period. Oecologia 160:795-806

Polito MJ, Fisher S, Tobias CR, Emslie SD (2009) Tissuespecific isotopic discrimination factors in gentoo penguin (Pygoscelis papua) egg components: implications for dietary reconstructions using stable isotopes. J Exp Mar Biol Ecol 372:106-112

Post DM (2002) Using stable isotopes to estimate trophic position: models, methods, and assumptions. Ecology 83: 703-718

Quillfeldt P, McGill RAR, Furness RW (2005) Diet and foraging areas of Southern Ocean seabirds and their prey inferred from stable isotopes: review and case study of Wilson's storm-petrel. Mar Ecol Prog Ser 295:295-304

Quillfeldt P, Masello JF, McGill RAR, Adams M, Furness RW (2010) Moving polewards in winter: a recent change in the migratory strategy of a pelagic seabird? Front Zool 2010: $7-15$

Reid K, Croxall JP (2001) Environmental response of upper trophic level predators reveals a system change in an Antarctic marine ecosystem. Proc Biol Sci 268:377-384

Ribic CA, Chapman E, Fraser WR, Lawson GL, Wiebe PH

Editorial responsibility: Yves Cherel,

Villiers-en-Bois, France
(2008) Top predators in relation to bathymetry, ice and krill during austral winter in Marguerite Bay, Antarctica. Deep-Sea Res II 55:485-499

Robbins CT, Felicetti LA, Florin ST (2010) The impact of protein quality on stable nitrogen isotope ratio discrimination and assimilated diet. Oecologia 162:571-579

> Satterthwaite FE (1946) An approximate distribution of estimates of variance components. Biometrics Bull 2:110-114

> Seminoff JA, Bjorndal KA, Bolten AB (2007) Stable carbon and nitrogen isotope discrimination and turnover in pond sliders Trachemys scripta: insights for trophic study of freshwater turtles. Copeia 534-542

Simkiss K, Tyler C (1958) Reactions between eggshell matrix and metallic cations. Q J Microsc Sci 99:5-13

Smith RC, Ainley D, Baker K, Domack E and others (1999) Marine ecosystem sensitivity to climate change. Bioscience 49:393-404

Tanton JL, Reid K, Croxall JP, Trathan PN (2004) Winter distribution and behaviour of gentoo penguins Pygoscelis papua at South Georgia. Polar Biol 27:299-303

Tierney M, Southwell C, Emmerson LM, Hindell MA (2008) Evaluating and using stable isotope analysis to infer diet composition and foraging ecology of Adélie penguins Pygoscelis adeliae. Mar Ecol Prog Ser 355:297-307

Trivelpiece WZ, Fraser W (1996) The breeding biology and distribution of Adélie penguins: adaptations to environmental variability. In: Ross RM, Hofmann EE, Quetin LB (eds) Foundations for ecological research west of the Antarctic Peninsula. Antarctic Research Series, Vol 70. American Geophysical Union, Washington, DC, p 273-285

Trivelpiece WZ, Trivelpiece SG (1990) Courtship period of Adélie, gentoo, and chinstrap penguins. In: Davis LS, Darby JT (eds) Penguin biology. Academic Press, San Diego, CA, p 113-127

> Trivelpiece WZ, Trivelpiece SG, Volkman NJ (1987) Ecological segregation of Adélie, gentoo and chinstrap penguins at King George Island, Antarctica. Ecology 68:351-361

Trivelpiece WZ, Trivelpiece SG, Geupel GR, Kjelmyr J, Volkman NJ (1990) Adélie and chinstrap penguins: their potential as monitors of the Southern Ocean marine ecosystem. In: Kerry KR, Hempel G (eds) Antarctic ecosystems: ecological change and conservation. Springer, Berlin, p 191-202

> Volkman NJ, Presler P, Trivelpiece W (1980) Diets of Pygoscelid penguins at King George Island, Antarctica. Condor 82:373-378

Wilson RP (2010) Resource partitioning and niche hypervolume overlap in free-living Pygoscelid penguins. Funct Ecol 24:646-657

Wilson RP, Alvarrez B, Latorre L, Adelung D, Culik B, Bannasch R (1998) The movements of gentoo penguins Pygoscelis papua from Ardley Island, Antarctica. Polar Biol 19:407-413

Woehler EJ (1993) The distribution and abundance of Antarctic and subantarctic penguins. Scientific Committee on Antarctic Research, Cambridge

Submitted: June 10, 2010; Accepted: October 5, 2010

Proofs received from author(s): December 11, 2010 